\title{
Influence of introduced vs. native parasites on the body condition of migrant silver eels
}

\author{
Claudia Gérard ${ }^{1, *}$, Thomas Trancart ${ }^{2}$, Elsa Amilhat ${ }^{3,4}$, Elisabeth Faliex ${ }^{3,4}$ Laure Virag $^{2}$, \\ Eric Feunteun ${ }^{2}$, and Anthony Acou ${ }^{2}$ \\ ECOBIO, CNRS, Université de Rennes, 1 avenue du Général Leclerc, 35042 Rennes, France \\ 2 UMR 7208 BOREA, CRESCO, Muséum National d'Histoire Naturelle, 38 rue du Port Blanc, 35800 Dinard, France \\ 3 CNRS, Centre de Formation et de Recherche sur les Environnements Méditerranéens, UMR 5110, 66860 Perpignan, France \\ ${ }^{4}$ Université de Perpignan Via Domitia, Centre de Formation et de Recherche sur les Environnements Méditerranéens, UMR 5110, \\ 66860 Perpignan, France
}

Received 27 August 2013, Accepted 9 October 2013, Published online 21 October 2013

\begin{abstract}
Because parasitism is among the reasons invoked to explain the collapse of Anguilla anguilla, we evaluated the parasitic constraint on body condition (BC) of migrant silver eels as a proxy of fitness with inter-site comparisons. Metazoan parasites were studied in 149 silver eels from five sites (northern Europe). In total, 89\% were infected by 13 species including Myxozoa, Monogenea, Cestoda, Nematoda, and Acanthocephala. Anguillicoloides crassus was most common (56\%), then Acanthocephalus clavula (30\%), and Pseudodactylogyrus sp. (17\%). BC, calculated for 58 females, was negatively correlated by abundance of the introduced Pseudodactylogyrus sp. but not by other parasite taxa. Nevertheless, the introduced A. crassus was considered as a severe pathogen based on previous data, whereas the native $A$. clavula was supposed to have limited impact. Parasite component communities and BC were different between sites. Silver eels from Stockholm Archipelago (Sweden) were the least parasitized (40\% vs. 90-95\% for other sites) with no parasites on the gills. Burrishoole (Ireland) differed by the absence of $A$. crassus and high prevalence of $A$. clavula (84\%) but without consequences on BC. Gudenaa (Denmark), Corrib (Ireland), and Frémur (France) were close due to high prevalence of $A$. crassus (89-93\%). Gudenaa and Corrib were the most similar because Pseudodactylogyrus sp. was also highly prevalent (respectively $71 \%$ and $60 \%$ ) whereas absent in Frémur. Our results suggest that the fitness loss induced by the introduced parasites could affect the spawning success of migrant silver eels from Gudenaa and Corrib, and to a lesser extent from Frémur, but probably not those from Stockholm Archipelago and Burrishoole.
\end{abstract}

Key words: Anguilla anguilla, Silver eels, Metazoan parasite communities, Introduced parasites, Body condition.

Résumé - Influence des parasites introduits vs natifs sur l'indice de condition des anguilles argentées migrantes. Parce que le parasitisme figure parmi les raisons évoquées pour expliquer le déclin d'Anguilla anguilla, nous avons évalué la contrainte parasitaire sur l'indice de condition (BC) comme mesure de la fitness chez des anguilles argentées en cours de migration avec une comparaison entre sites. Les métazoaires parasites ont été étudiés chez 149 anguilles argentées de 5 sites (Europe du Nord). Au total, 89 \% étaient infectées par 13 espèces parmi les Myxozoa, Monogenea, Cestoda, Nematoda et Acanthocephala. Anguillicoloides crassus était la plus commune (56\%), puis Acanthocephalus clavula (30\%), et Pseudodactylogyrus sp. (17\%). Le BC, calculé pour 58 femelles, était négativement influencé par l'abondance du parasite introduit Pseudodactylogyrus sp. mais pas par les autres taxons. Néanmoins, A. crassus est considérée comme un pathogène introduit sévère selon les données déjà publiées, alors que l'espèce native $A$. clavula est supposée avoir un impact limité. Les communautés parasitaires et le BC étaient différents selon les sites. Les anguilles argentées de Stockholm Archipelago (Suède) étaient les moins parasitées (40\% vs. 90-95\% pour les autres sites) et n'abritaient pas de parasites dans leurs branchies. Burrishoole (Irlande) différait par l'absence d'A. crassus et une forte prévalence d'A. clavula (84\%) mais sans conséquences sur le BC. Gudenaa (Danemark), Corrib (Irlande) et Frémur (France) étaient proches en raison de la prévalence élevée d'A. crassus (89-93\%). Gudenaa et Corrib étaient les plus similaires car Pseudodactylogyrus sp. était aussi fortement prévalent (respectivement $71 \%$ et $60 \%$ ) mais absent dans le Frémur. Nos résultats suggèrent que la perte de fitness induite par les parasites introduits pourrait affecter le succès de la reproduction des anguilles argentées migrantes originaires de Gudenaa et Corrib, et dans une moindre mesure du Frémur, mais probablement pas de celles de Stockholm Archipelago et Burrishoole.

\footnotetext{
*Corresponding author: claudia.gerard@univ-rennesl.fr
}

This is an Open Access article distributed under the terms of the Creative Commons Attribution License (http://creativecommons.org/licenses/by/2.0), which permits unrestricted use, distribution, and reproduction in any medium, provided the original work is properly cited. 


\section{Introduction}

In spite of the perennial scientific mysteries about its biology and population genetic structure, the European eel Anguilla anguilla is considered as panmictic, therefore a breeder emigrating from a given river theoretically contributes to subsequent glass eel recruitment along the whole continental distribution range $[5,16,21]$. Depending on subpopulations and habitat characteristics, eels spend about 3-30 years in fresh and brackish waters of Europe and North Africa, growing and accumulating fat reserves for an active swimming migration as silver eel stage across the Atlantic Ocean and reproduction once in the Sargasso Sea [36]. The probability that silver eels reach the spawning grounds and reproduce successfully is likely to vary greatly among continental growing sites $[4,18]$. A panEuropean methodology to estimate the overall breeding potential of silver eels according to relevant criteria (e.g., fat composition, contamination by chemicals, parasitic load) is not ready for use because of the complexity in implementing such an approach. The use of silver eel condition indices may constitute a first step in this direction. Body condition has been demonstrated to indicate energy reserves of Salmo salar [59], Coregonus artedi [54], and Gadus morhua [25, 40]. Considering the importance of energy reserves during both transoceanic migration and reproduction of the European eel [7], we hypothesize that body condition may represent a good proxy of silver eel fitness [4, 31].

Because most parasitized organisms are generally in poorer condition than unparasitized ones [15, 22, 61 for reviews] and because parasites interact with natural and anthropogenic stressors to increase mortality and reduce animal health in myriad ways [47 for review], parasitism is among the reasons invoked to explain the European eel collapse [9, 20, 28, 35]. Up to now, 161 species or taxa have been described in A. anguilla from fresh, brackish, and marine waters in 30 countries of Europe and North Africa [32 for review]. Among them, the introduced Anguillicoloides crassus (swimbladder nematode) and Pseudodactylogyrus sp. (gill monogenean) are considered as an important factor able to induce a stress that probably decreases the host fitness and seriously hampers the recovery of the European eel [for reviews: 9, 35]. The scientific research program EELIAD (2008-2012) aimed to resolve some of the mysteries of eel biology in order to help conserving European eel stocks. EELIAD provided us the opportunity to investigate the parasitism patterns of some organs (gills, heart, intestine, and swimbladder) of silver eels sampled at the start of their transoceanic migration across five far-distant sites from northern Europe, i.e., Sweden, Denmark, Ireland (two sites), and France. Our objectives were (i) to describe the metazoan parasite community of these five silver eel subpopulations, and (ii) to evaluate in each site the potential parasitic constraint (on the whole and depending on parasite taxa) on the body condition of silver eels. Because a greater pathogenicity is often observed for recent (vs. long-term coevolved) host-parasite associations as for Pseudodactylogyrus sp. and A. crassus in A. anguilla [33, 34,48 ], we suppose that the least parasitized silver eels by these introduced species could be the most susceptible to reach the

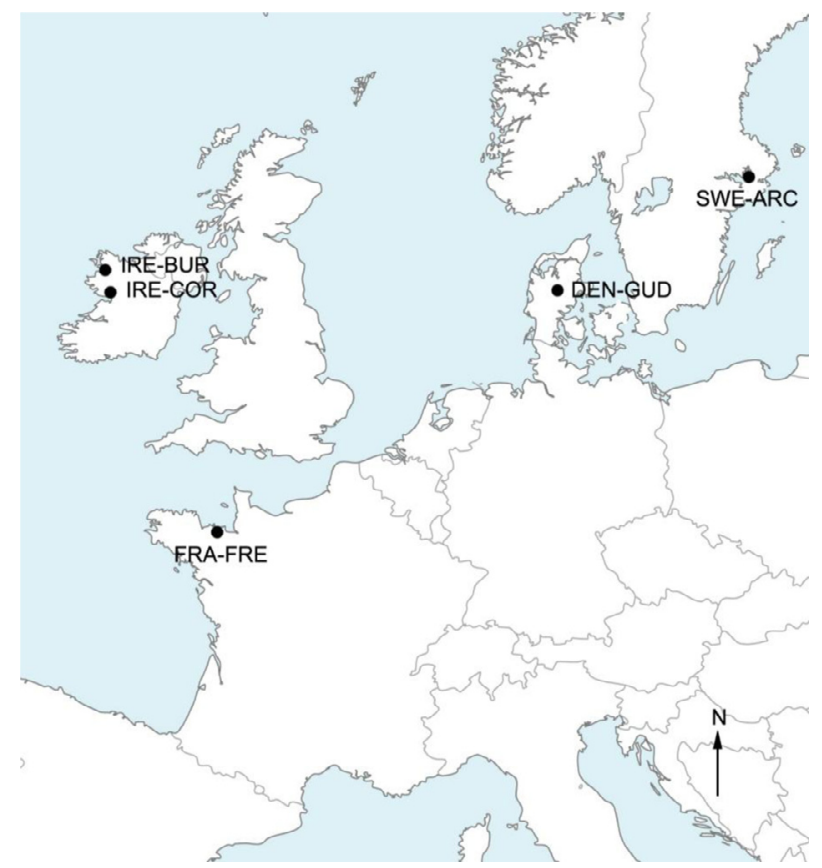

Figure 1. Geographical position of the sample sites of Anguilla anguilla in northern Europe: Burrishoole (IRE-BUR) and Corrib (IRE-COR) in Ireland, Frémur in France (FRA-FRE), Gudenaa in Denmark (DEN-GUD), and Stockholm Archipelago in Sweden (SWE-ARC).

spawning grounds and to reproduce in the Sargasso Sea compared to the most heavily infected ones.

\section{Materials and methods}

\section{Study areas and silver eel sampling (Figure 1; Table 1)}

Silver eels (149) were caught during their seaward migration between October and February (i.e., at the beginning of their transoceanic migration) in five coastal water bodies from northern Europe: Stockholm Archipelago in Sweden (SWEARCH, $n=10$, Oct 2009), River Gudenaa in Denmark (DEN-GUD, $n=21$, Dec 2009), Burrishoole (IRE-BUR, $n=49$, Nov 2008), and Corrib (IRE-COR, $n=26$, Nov 2009) in Ireland, and River Frémur in France (FRA-FRE, $n=43$, Feb 2010). The eel collection was focused on silver eel stage at the same maturation degree (see below the three criteria for silver eel assessment). Migrant silver eels were intercepted using pound nets (SWE-ARCH), coghill nets (IRECOR), or eel-traps installed on dams (DEN-GUD, IRE-BUR, and FRA-FRE) depending on the site, these different methods of capture being adapted to both the size of the eels and the studied systems. Water bodies sampled differed in trophic status and level of anthropogenic pressure (Table 1). Among sites, IRE-BUR is considered as the pristine reference site due to 


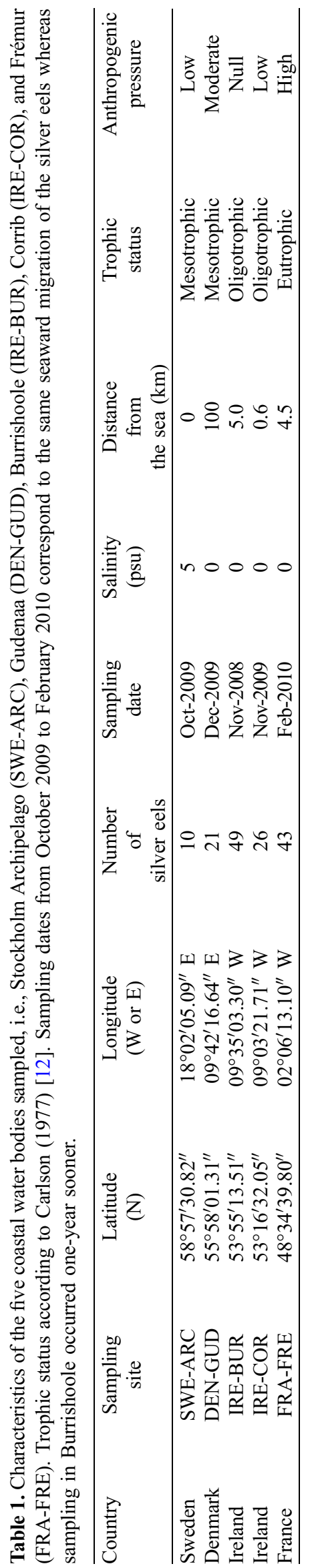

the clean water and null anthropogenic pressure (no fishery, controls on movement of boat, water, or fishing gear).

\section{Silver eels: Development stage and sex determination, aging by otoliths}

Each fish collected was anesthetized with Benzocaine at a concentration of $0.15 \mathrm{~g} \mathrm{~L}^{-1}$. Then, total weight (TW, g) and total length $(\mathrm{TL}, \mathrm{mm})$ were measured respectively to the nearest $\mathrm{g}$ and $\mathrm{mm}$. Silver eels were identified by three criteria $[1,2]$ : color of the back and belly, presence of a well-defined lateral line, as well as ocular index $(O I \geq 6.5$, Pankhurst's 1982).

The sex was assigned by macroscopic observation of the gonads using the criteria described by Colombo et al. [14]. Because most silver eels sampled were females (132 vs. 17 males), we only selected female eels to study the parasitic impact on the eel body condition.

As a proxy of fitness, we used index developed by Le Cren [41] by calculating the body condition (BC) as the relative total weight $\mathrm{TWr}=100 \mathrm{TW} / \mathrm{TW}$ std, where TWstd is the predicted standard total weight of a fish at the same TL, as calculated according to the $\log _{10} \mathrm{TW}-\log _{10} \mathrm{TL}$ regression equation (least squares means fit) for the whole sample of 132 female silver eels.

A sample of 58 female silver eels (SWE-ARCH, $n=4$; DEN-GUD, $n=10$; IRE-BUR, $n=17$; IRE-COR, $n=11$; FRA-FRE, $n=16$ ) was aged by examination of the sagittal otoliths. The extracted otoliths were glued dorsal side up with crystal bond, grounded along the longitudinal plane until the nucleus was reached. Following the method described by the EIFAC ICES working group on eel [30], the fish continental age (number of years in fresh water) was determined through a stereomicroscope by counting the number of annuli from the first growth check outside the so-called zero band. This band is commonly assumed as the beginning of eel's continental growth.

\section{Parasitological research in sampled Anguilla anguilla}

All the 149 silver eels sampled were frozen before the research of metazoan parasites made on the gills, the heart, the digestive tract, and the swimbladder (the other organs were not available for parasitic investigation). Each organ was dissected using binocular microscope and all the metazoan parasites were numbered per organ and per eel (except for Myxozoa for which the presence or absence of cysts was recorded), identified and preserved in alcohol $70^{\circ}$. The parasitological parameter used to describe the community structure of parasites was species richness (number of parasite species in a sample of hosts); those to describe parasite populations (for a given parasite species) were prevalence (number of hosts infected with a particular parasite species/number of examined hosts), mean abundance (average abundance of a parasite species among all members of a host sample), and mean intensity (total number of parasites of a particular species found in a 


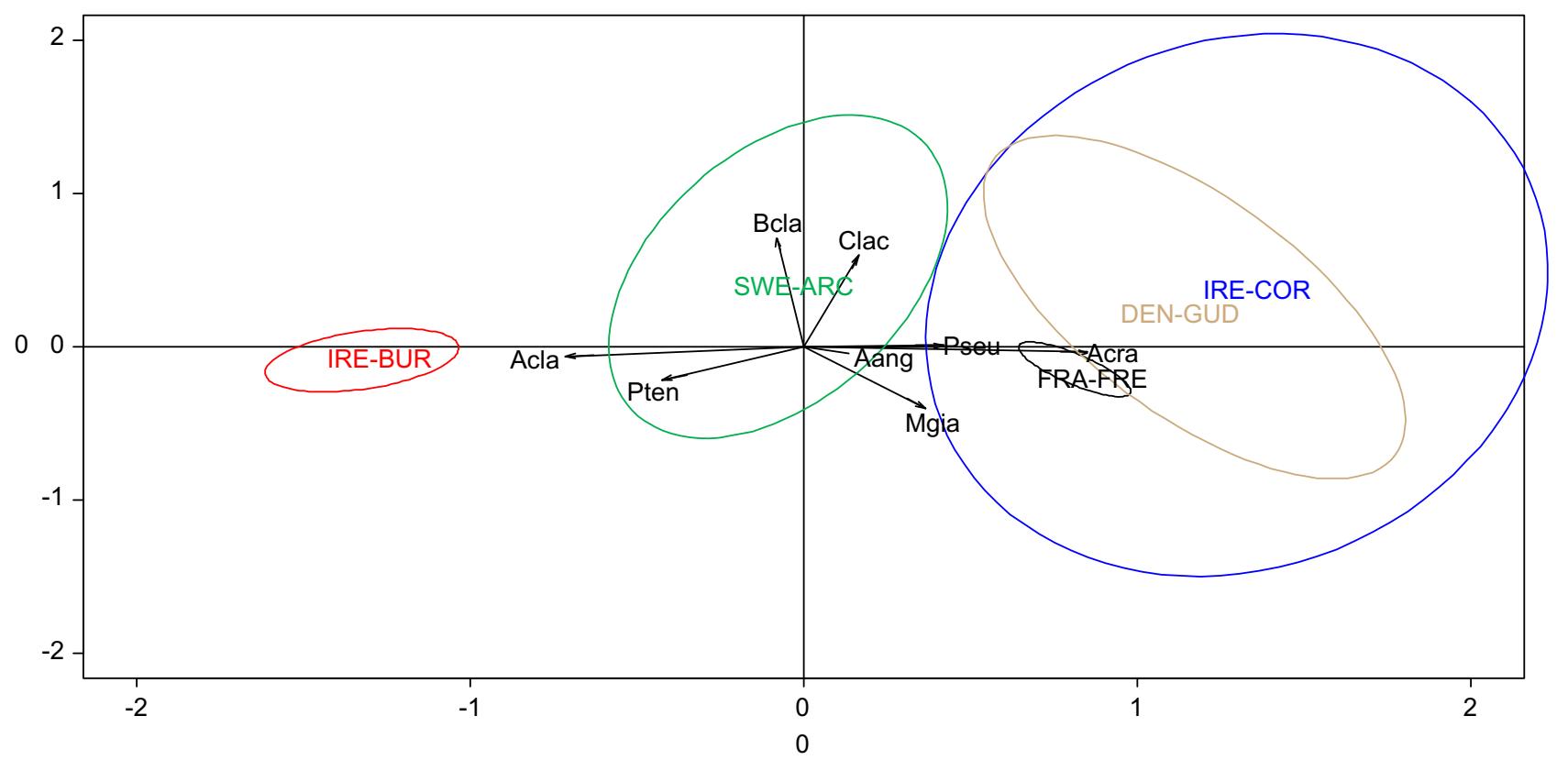

Figure 2. Factorial map according to the Multiple Correspondence Analysis on the presence/absence of the eight parasite taxa [Acanthocephalus anguillae (Aang), Acanthocephalus clavula (Acla), Anguillicoloides crassus (Acra), Bothriocephalus claviceps (Bcla), Camallanus lacustris (Clac), Myxidium giardia (Mgia), Paraquimperia tenerrima (Pten), and Pseudodactylogyrus sp. (Pseu)] in silver eels from the five study-sites (DEN-GUD, FRA-FRE, IRE-BUR, IRE-COR, and SWE-ARC).

sample divided by the number of hosts infected with that parasite) [10].

\section{Statistical analyses}

All the statistical analyses were made with the R-Cran project free software (http://www.r-project.org/). Differences were considered statistically significant at $p<0.05$. Mean values of data are reported as means \pm standard error $(S E)$ except for prevalences $\pm 95 \%$ confidence limits $(C L)$.

\section{Inter-site comparison of the communities of parasites}

Taxa with low prevalence $(\leq 2 \%)$ were excluded of the analysis (Acanthocephalus lucii, Echinorhynchus truttae, Eustrongylides sp., Pomphorhynchus laevis, and Raphidascaris acus) because of their rarity and probable limited impact on silver eel subpopulations.

First, the structure of the component parasite communities in silver eels $(n=149)$ among the five sites was detected and represented by a Multiple Correspondence Analysis (MCA, Ade4 package) performed on the presence/absence of eight parasite taxa (Myxidium giardi, Pseudodactylogyrus sp., Bothriocephalus claviceps, A. crassus, Paraquimperia tenerrima, Camallanus lacustris, Acanthocephalus clavula, and Acanthocephalus anguillae). Second, similar tests (MCA) were focused on the abundances of the three major parasite taxa (i.e., the two introduced A. crassus and Pseudodactylogyrus sp., and the native $A$. clavula) that could exert a significant constraint on silver eels, potentially compromising the migration and spawning success [28, 35]. In factorial maps (Figures 2 and 3) realized from MCA results, ellipses are only visual summary. The prob- ability to be located in the ellipse is $p=1-\exp \left(-\mathrm{k}^{2} / 2\right)$ with $k=1.5$ showing that around $67 \%$ of observations were located in the ellipses.

\section{Factors influencing the body condition of female silver eels}

Five variables which could explain $\mathrm{BC}$ were chosen: the age of female silver eels, the study-site, and the number of each of the three major parasite taxa (A. crassus, A. clavula, and Pseudodactylogyrus sp.). Their influence was analyzed using generalized linear models (glm, base package). We tested all possible combinations with these variables including interactions. Nineteen different models were tested and compared using classical selection by both step-akaike information criterion corrected from small sample sizes (AICc) and deviance explained (DE) [29]. Then, the effect of parameters was analyzed by analysis of variance (ANOVA) from the selected model. As the sample size (58) used for the glm analyses was small according to the number of study-sites and variables tested, a power test using pwr package (pwr.f2.test) was performed on the selected model in order to give confidence in the acceptation of the null hypothesis (the fitness loss was not affected in some localities).

\section{Results}

\section{Composition of the metazoan parasite community}

A total of 149 European silver eels were dissected among them $89 \pm 5 \%$ (132) were infected by one to six metazoan parasite taxa among the 13 identified in the whole sampling (Table 2). No trematodes were found. The nematode $A$. crassus, 


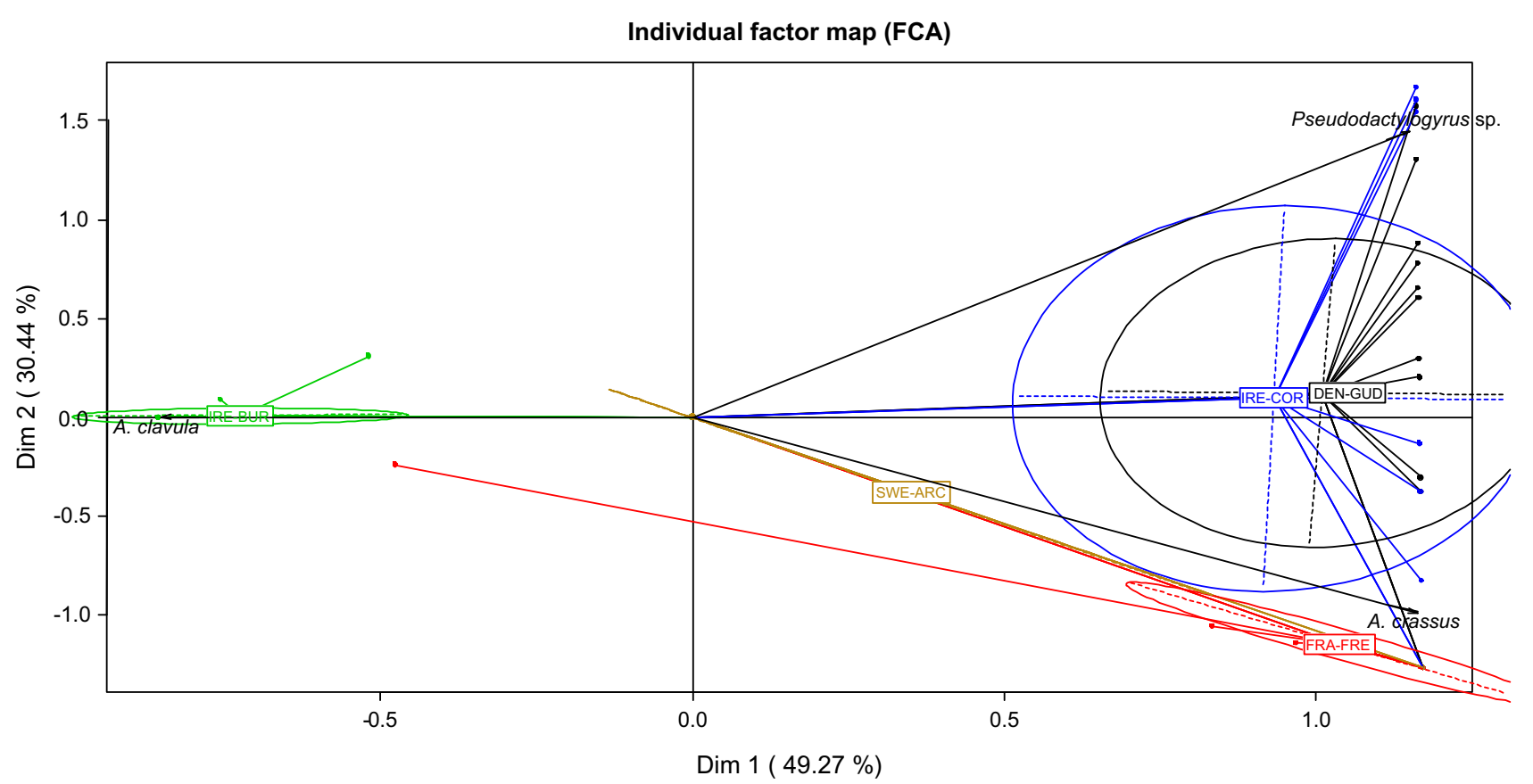

Figure 3. Factorial map according to the Multiple Correspondence Analysis on the abundance of the three major parasite taxa (Acanthocephalus clavula, Anguillicoloides crassus, and Pseudodactylogyrus sp.) in silver eels from the five study-sites (DEN-GUD, FRAFRE, IRE-BUR, IRE-COR, and SWE-ARC)

Table 2. Metazoan parasite species and their ecological parameters in Anguilla anguilla (149) from the five study-sites (CL 95\% was calculated for each prevalence).

\begin{tabular}{|c|c|c|c|c|c|}
\hline Species & Abbreviations & $\begin{array}{c}\text { Prevalence } \\
\% \\
\end{array}$ & CL95\% & $\begin{array}{c}\text { Microhabitat } \\
\text { in eels }\end{array}$ & Diet \\
\hline \multicolumn{6}{|l|}{ Myxozoa } \\
\hline Myxidium giardi (Cépède, 1906) [13] (cysts) & Mgia & 4.5 & 3.3 & Gill & - \\
\hline \multicolumn{6}{|l|}{ Monogena } \\
\hline Pseudodactylogyrus sp. & Pseu & 17.3 & 6.1 & Gill & Surface browser \\
\hline \multicolumn{6}{|l|}{ Cestoda } \\
\hline Bothriocephalus claviceps (Goeze, 1782) [24] & Bcla & 2.7 & 2.6 & Intestine & Osmotrophe \\
\hline \multicolumn{6}{|l|}{ Nematoda } \\
\hline Anguillicoloides crassus (Kuwahara, Niimi \& Hagaki, 1974) [39] & Acra & 56.0 & 8.0 & Swimbladder & Hematophagous \\
\hline Camallanus lacustris (Zoega, 1776) [50] & Clac & 2.7 & 2.6 & Intestine & Hematophagous \\
\hline Paraquimperia tenerrima (Linstow, 1878) [45] & Pten & 4.7 & 3.4 & Intestine & Chyle feeder \\
\hline Raphidascaris acus (Bloch, 1779) [6] & Racu & 1.3 & 1.8 & Intestine & Chyle feeder \\
\hline Eustrongylides sp. (cysts) & Eust & 0.7 & 1.3 & Stomach wall & - \\
\hline \multicolumn{6}{|l|}{ Acanthocephala } \\
\hline Acanthocephalus anguillae (Müller, 1780) [51] & Aang & 6.0 & 3.8 & Intestine & Osmotrophe \\
\hline Acanthocephalus lucii (Müller, 1776) [50] & Aluc & 2.0 & 2.3 & Intestine & Osmotrophe \\
\hline Acanthocephalus clavula Dujardin, 1845 [17] & Acla & 30.2 & 7.4 & Intestine & Osmotrophe \\
\hline Echinorhynchus truttae Schrank, 1788 [57] & Etru & 0.7 & 1.3 & Intestine & Osmotrophe \\
\hline Pomphorhynchus laevis (Müller, 1776) [50] & Plae & 1.3 & 1.8 & Intestine & Osmotrophe \\
\hline
\end{tabular}

the only species recorded in the swimbladder, was the most common (prevalence of $56 \pm 8 \%$, mean intensity of $9.01 \pm 1.19$, and mean abundance of $4.98 \pm 0.76$ ), followed by $A$. clavula $(30 \pm 7 \%, 28.16 \pm 4.17$, and $8.45 \pm 1.64)$ in the intestine, and then Pseudodactylogyrus sp. $(17 \pm 6 \%$, $18.78 \pm 4.73$, and $2.47 \pm 0.78$ ) on the gills.

\section{Component communities of metazoan parasites in each subpopulation of Anguilla anguilla}

According to the MCAs (Figures 2 and 3), the structure of the parasite component communities (Table 3) varied among the study-sites both on the presence/absence of the total parasite 
taxa and on the abundance of the three most prevalent taxa ( $A$. crassus, A. clavula, and Pseudodactylogyrus sp.).

IRE-BUR strongly differed from the four other sites. First, it was the only site where $A$. crassus was completely absent. Second, the intestine was heavily infected with a total prevalence of $90 \%(C L=78-97 \%)$, mostly by the acanthocephalan A. clavula that was highly occurrent in terms of prevalence (84\% with $C L=71-93 \%)$, mean intensity $(30.51 \pm 4.40)$, and mean abundance $(25.53 \pm 4.02)$. A second site, SWEARC, was also significantly different from the others (even with the small sample size of 10 fish compared to other sites) due to an overall prevalence less than half $(40 \%$ with $\mathrm{CL}=12$ $74 \%$ vs. $90-95 \%$ with $\mathrm{CL}=77-100 \%$ in other sites) and to a total absence of parasites on the gills (Table 3). The three other sites: DEN-GUD, IRE-COR, and FRA-FRE, were characterized by high prevalences of $A$. crassus varying from $89 \%$ $(C L=67-104 \%)$ to $93 \%(80-99 \%)$. Among all sites, DENGUD and IRE-COR were the most similar because of the highest species richness (eight parasite taxa vs. four and five in other sites) and of the highest prevalences of Pseudodactylogyrus sp.; no monogenean was found in silver eels from FRA-FRE (Table 3).

\section{Influence of parasitism on the body condition of female silver eels}

Results from the 19 linear models are summarized in Table 4. According to the two criterions of selection (AICc and DE), the model \#18 was selected. Results of ANOVA performed on this model are summarized in Table 5 . The selected model explained $42.43 \%$ of the total deviance, and $33.10 \%$ of this explained deviance was explained only by the site (or $14.04 \%$ of total deviance, $p=0.013$ ). The combined effect of female age and study-site was responsible of $27.70 \%$ of the explained deviance $(p=0.061)$. Among the three major parasite taxa, the number of Pseudodactylogyrus sp. had a strong negative effect on the $\mathrm{BC}$ of female silver eels $(p=0.003)$ and explained $27.10 \%$ of the explained deviance. The number of $A$. crassus tends to have a positive effect on the $\mathrm{BC}$ $(p=0.048)$. Model selection using step-AICc process showed that $A$. clavula had no significant effect on the BC. Indeed, AICc and explained deviance were not different between models \#18 and \#19, this latter being similar to \#18 but with A. clavula as additional variable (Table 5).

\section{Discussion}

Whatever the host-parasite combination, parasites and their host compete for resources in such a way that both survival and fecundity of the host could be affected, even if no pathology is obvious and even if this effect may be drowned in the background noise of all other factors that affect survival and fecundity $[15,22,52,61$ for reviews]. Other environmental stressors (e.g., pollutants, pathogens) that can also influence the health status of the eels $[3,23,26,56]$ could be considered as a potential confounding factor, but in most cases, contaminants and parasites occurring together are shown to exacerbate the detrimental effects on individuals (synergistic effects), suggesting 
Table 4. List of all the 18 models tested with AICc (akaike information criterion corrected from small sample sizes) and DE (deviance explained, \%); $\mathrm{BC}=$ body condition.

\begin{tabular}{|c|c|c|c|}
\hline No. & Model & AIC & $\mathrm{DE}$ \\
\hline 1 & $\mathrm{BC} \sim$ site & 393.13 & 14.04 \\
\hline 2 & $\mathrm{BC} \sim$ age & 390.25 & 12.23 \\
\hline 3 & $\mathrm{BC} \sim$ Pseudodactylogyrus sp. & 394.03 & 5.86 \\
\hline 4 & $\mathrm{BC} \sim$ A. clavula & 396.10 & 2.19 \\
\hline 5 & $\mathrm{BC} \sim$ A. crassus & 397.04 & 0.47 \\
\hline 6 & $\mathrm{BC} \sim$ site + age & 389.05 & 23.19 \\
\hline 7 & $\mathrm{BC} \sim$ site + age + Pseudodactylogyrus sp. & 384.96 & 31.38 \\
\hline 8 & $\mathrm{BC} \sim$ site + age $:$ site + Pseudodactylogyrus sp. + A. clavula & 387.90 & 37.51 \\
\hline 9 & $\mathrm{BC} \sim$ site + age + Pseudodactylogyrus $\mathrm{sp} .+$ A. clavula + A. crassus & 384.83 & 36.42 \\
\hline 10 & $\mathrm{BC} \sim$ site + age + Pseudodactylogyrus sp.:site + A. clavula $:$ site + A. crassus $:$ site & 389.27 & 40.49 \\
\hline 11 & $\mathrm{BC} \sim$ site + age: $:$ ite + Pseudodactylogyrus sp.:site + A. clavula $:$ site $+A$. crassus $:$ site & 389.27 & 46.74 \\
\hline 12 & $\mathrm{BC} \sim$ age:site + Pseudodactylogyrus sp.:site + A. clavula $:$ site + A. crassus $:$ site & 388.67 & 41.14 \\
\hline 13 & $\mathrm{BC} \sim$ site + site:age + Pseudodactylogyrus sp.:site + A. crassus $:$ site & 385.78 & 46.24 \\
\hline 14 & $\mathrm{BC} \sim$ site + age:site + Pseudodactylogyrus sp.:site & 387.90 & 37.51 \\
\hline 15 & $\mathrm{BC} \sim$ site + age:site + Pseudodactylogyrus sp.:site + A. clavula $:$ site & 391.39 & 38.10 \\
\hline 16 & $\mathrm{BC} \sim$ site + age + Pseudodactylogyrus sp. $:$ site + A. clavula $:$ site & 390.44 & 32.04 \\
\hline 17 & $\mathrm{BC} \sim$ site + age + Pseudodactylogyrus sp. + A. crassus & 382.84 & 36.42 \\
\hline 18 & $\mathrm{BC} \sim$ site + age $:$ site + Pseudodactylogyrus sp. + A. crassus & 382.44 & 42.43 \\
\hline 19 & $\mathrm{BC} \sim$ site + age $:$ site + Pseudodactylogyrus $\mathrm{sp} .+$ A. crassus + A. clavula & 385.47 & 42.43 \\
\hline
\end{tabular}

Table 5. Deviance explained (\%) by each significant variable (studysite, Pseudodactylogyrus sp., Anguillicoloides crassus and site:age) of the selected model.

\begin{tabular}{lcc}
\hline Variables & Deviance & $P$-value \\
\hline Study-site & 14.04 & 0.013 \\
Pseudodactylogyrus sp. & 11.50 & 0.003 \\
A. crassus & 5.12 & 0.048 \\
Site:age & 11.77 & 0.061 \\
Total deviance explained & 42.43 & 0.002 \\
\hline
\end{tabular}

that parasitized fish in polluted environments are in a poorer condition than unparasitized fish [47 for review]. Thus, to consider parasitism and its impact can help to understand the collapse of the European eel. In our study, $89 \pm 5 \%$ of all silver eels were parasitized and 13 metazoan taxa were identified including Myxozoa, Monogenea, Cestoda, Nematoda, and Acanthocephala commonly recorded in A. anguilla [32 for review]. No Trematoda were found from any site in spite of 39 trematode species described in A. anguilla as definitive host [32]. One possible explanation is that our silver eels were originated from waters with salinity $\leq 5 \mathrm{psu}$ and that trematodes infecting eels are shown to be significantly less frequent in fresh vs. marine waters $[37,38]$.

The body condition of silver eels was used as a proxy of fitness that can reveal the impact of parasite infections. Among the three major parasite taxa recorded in the female silver eels studied here (A. crassus, A. clavula, and Pseudodactylogyrus sp.), only Pseudodactylogyrus sp. decreased the host body condition in relation with increasing abundance (up to 80 worms) on the gills. Pseudodactylogyrus sp. is the third more prevalent taxon in this study $(17 \pm 6 \%)$ and a specific gill monogenean of the genus Anguilla transferred from its native host Anguilla japonica to A. anguilla after introduction in Europe in 1977
[33, 35, 62]. Pseudodactylogyrus sp. is browsing the host gill surface and induces epithelial lesions potentially leading to lethal hypoxia of the highly susceptible European eel and facilitating infections by various opportunist pathogens (virus, bacteria, and fungi) [33, 35, 62].

In contrast with Pseudodactylogyrus sp., the infection by the introduced hematophagous $A$. crassus, the most prevalent species $(56 \pm 8 \%)$, had no significant effect on the condition factor of $A$. anguilla, as also shown by other studies [58 for review], and even tended to have a positive effect with increasing nematode abundance in the swimbladder. But this criterion is not the best reflecting the eel pathogenicity due to the short life cycle of $A$. crassus, and severely damaged swimbladders are shown to harbor very few or even no living nematodes [42, 63]. Nevertheless, using the Swimbladder Degenerative Index, Lefebvre et al. [44] recently demonstrated that the most affected eels had greater body length and mass $(+11 \%$ and $+41 \%$ respectively) than unaffected eels of the same age. Despite these surprising counterintuitive results, high virulence and severe impacts of $A$. crassus are expected because $A$. anguilla lacks an adaptive immune response, and various pathogenic potentially lethal effects (e.g., anemia, energy drain, swimming performance decrease) have been demonstrated, threatening the success of spawning migration in the Sargasso Sea [35, 43, 44, $53,58]$.

The body condition of female silver eels was also not influenced by the second most prevalent parasite of our study, $A$. clavula $(30 \pm 7 \%)$, a native generalist acanthocephalan with A. anguilla as preferred definitive host $[8,11]$. The apparent unchanged fitness of $A$. clavula-infected eels is in accordance with the absence of pronounced symptoms of disease generally observed for most fish infected by acanthocephalans (including those with high parasite intensities) [60 for review].

Component communities of metazoan parasites and body condition of silver eels widely varied between sites, suggesting 
differences in biocenosis (e.g., host species occurrence) and environmental constraints or stressors (including parasitism), with probable consequences on the spawning migration and reproduction success. Based on the inter-site differences and the virulence of Pseudodactylogyrus sp. and A. crassus, the silver eels from Stockholm Archipelago (Sweden) and from Burrishoole (Ireland) could be the most successful, whereas the migration success may be affected by the pathogenic effects of introduced parasites for the silver eels from the other sites studied, i.e., Frémur (France), Corrib (Ireland), and Gudenaa (Denmark). Indeed, only four out of the ten Swedish silver eels were infected and always with a very low parasite intensity. Moreover, they harbored no parasites on their gills and had both low $A$. crassus intensity (one helminth per swimbladder) and prevalence (three out of ten fish) suggesting low parasite pathogeny. Therefore, despite the low sample size, one can suppose that metazoan parasites have probably a limited influence on the condition of Swedish silver eels and on their migration success.

Burrishoole is considered as a pristine site with oligotrophic acid waters, no anthropogenic influence, and low levels of organic contaminants [46]. The growth rate of eels from this site is known to be extremely low [55], thus we consider that the one-year sooner sampling date (compared to the four other sites) had no significant impact on the eel parasite community and did not introduce a bias in our inter-site comparison. In our study, $90 \pm 8 \%$ of the silver eels from Burrishoole were parasitized but this high total prevalence was not synonym of a strong parasitic constraint since they were mainly infected by the native intestinal acanthocephalan $A$. clavula (prevalence of $84 \pm 10 \%$, intensity of $31 \pm 4$ ) for which we demonstrated no influence on the host body condition. A. crassus was not recorded suggesting that the nematode may not complete its entire life cycle in Burrishoole despite its numerous intermediate crustacean (ostracods, copepods) and paratenic fish (and even snails) hosts [27, 49]. Moreover, no parasitic pathology probably occurred in the gills of Burrishoole silver eels because of the rarity of Pseudodactylogyrus sp. (only two infected out of the 49 specimens, harboring only one or three monogeneans).

Despite differences in the anthropogenic influence and the trophic status of Frémur (France), Corrib (Ireland), and Gudenaa (Denmark), A. crassus was omnipresent in A. anguilla from these sites with a prevalence varying from $89 \%(67 / 104)$ to 93\% (80/99) probably inducing pathogenic effects [35 for review]. In addition, for 60\% (36/81) and 71\% (49/87) of the Corrib and Gudenaa silver eels, hypoxia due to the impaired gills was probably a major symptom as they were severely infected by Pseudodactylogyrus sp. with a mean intensity of $23 \pm 12$ and $19 \pm 6$ respectively. The parasite constraint appeared more substantial for the silver eels from Corrib and Gudenaa having both damaged swimbladder and gills than for those from Frémur since Pseudodactylogyrus sp. was absent.

Finally, based on the potential fitness loss induced by parasitism, we suppose that the migrant silver eels from Stockholm Archipelago (Sweden) and Burrishoole (Ireland) are able to contribute to the recruitment and gene pool of $A$. anguilla pop- ulation, whereas those from our other study-sites [in particular from Corrib (Ireland) and Gudenaa (Denmark)] have a lower probability to reach the spawning grounds in Sargasso Sea.

Numerous aspects remain to be explored to explain the decline of the European eel population, probably induced by various interacting abiotic and biotic factors (e.g., habitat loss or fragmentation, changing hydrology, overfishing, pollution, and pathogens $[9,20,21,28,36,56])$ and resulting in difficult and complex measures of preservation of this species. Enhancing the production of viable silver eels by water system represents the current target of the conservation strategy of the European eel [19]. However, we believe that the question of animal quality among river systems, which is presumed to influence the reproductive success, is also a key issue that must be urgently pursued for European eel conservation. Every potential impact on silver eel body condition warrants examination, more especially as synergistic effects can occur between environmental stressors such as parasites and contaminants, increasing the mortality of exposed organisms [47 for review].

Acknowledgements. We would like to thank Dave Righton that supervised the EELIAD program and all European collaborators for providing the fish used in this study (Håkan Wickström, Niklas Sjoberg, Kim Aarestrup, Russel Poole, Michael Ingemann Pedersen, Gustavo Becerra-Jurado, Paddy Gargan, Alan Walker, Fish Pass, and Bretagne Grands Migrateurs). This study was funded by Grant Agreement GOCE-2008212133 (EELIAD) of the European Union FP7 research program.

\section{References}

1. Acou A, Boury P, Laffaille P, Crivelli AJ, Feunteun E. 2005. Towards a standardized characterization of the potentially migrating silver European eel (Anguilla anguilla L.). Archiv für Hydrobiologie, 164, 237-255.

2. Acou A, Poizat G, Crivelli AJ. 2006. Errors in ocular index measurements in European eel Anguilla Anguilla (L.). Ecology of Freshwater Fish, 15, 578-582.

3. Acou A, Robinet T, Lance E, Gérard C, Mounaix B, Brient L, Le Rouzic B, Feunteun E. 2008. Evidence of silver eels contamination by microcystin-LR at the onset of their seaward migration: What consequences for their breeding potential? Journal of Fish Biology, 72, 753-762.

4. Acou A, Gabriel G, Laffaille P, Feunteun E. 2009. Differential production and condition indices of premigrant eels (Anguilla anguilla) in two small Atlantic coastal catchments of France, in Eels at the Edge: Science, Status, and Conservation Concerns, Casselman J, Cairns D (Eds.), Vol. 58, American Fisheries Society Symposium, p. 157-174.

5. Als TD, Hansen MM, Maes GE, Castonguay M, Riemann L, Aarestrup KA, Munk P, Sparholt H, Hanel R, Bernatchez L. 2011. All roads lead to home: panmixia of European eel in the Sargasso Sea. Molecular Ecology, 20, 1333-1346.

6. Bloch ME. 1782. Abhandlung von der Erzeugung der Eingeweidewürmer und den Mitteln wider dieselben. Bei Siegismund Friedrich Hesse.

7. Boëtius I, Boëtius J. 1980. Experimental maturation of female silver eels, Anguilla anguilla. Estimates of fecundity and energy reserves for migration and spawning. Dana, 1, 1-28. 
8. Brown AF, Chubb JC, Veltkamp CJ. 1986. A key to the species of Acanthocephala parasitic in British freshwater fishes. Journal of Fish Biology, 28, 327-334.

9. Bruslé J. 1994. L'anguille européenne Anguilla anguilla, un poisson sensible aux stress environnementaux et vulnérable à diverses atteintes pathogènes. Bulletin Français de la Pêche et de la Pisciculture, 335, 237-260.

10. Bush AO, Lafferty KD, Lotz JM, Shostak AW. 1997. Parasitology meets ecology on its own terms: Margolis et al. revisited. Journal of Parasitology, 83, 575-583.

11. Byrne CJ, Holland CV, Walsh E, Mulligan C, Kennedy CR, Poole WR. 2004. Utilization of brown trout Salmo trutta by Acanthocephalus clavula in an Irish lake: is this evidence of a host shift. Journal of Helminthology, 78, 201-204.

12. Carlson RE. 1977. A trophic state index for lakes. Limnology and Oceanography, 22, 361-369.

13. Cépède C. 1906. Myxidium giardi Cépède, et la prétendue immunité des Anguilles à l'égard des infections myxosporidiennes. Compte rendu des Séances de la Société de Biologie, 6, 170-173.

14. Colombo G, Grandi G, Rossi R. 1984. Gonad differentiation and body growth in Anguilla anguilla L. Journal of Fish Biology, 24, 215-228.

15. Combes C. 1995. Interactions durables. Écologie et évolution du parasitisme. Masson, Paris.

16. Dannewitz J, Maes GE, Johansson L, Wickström H, Volckaert FAM, Järvi T. 2005. Panmixia in the European eel: a matter of time... Proceedings of the Royal Society B, 272, 1129-1137.

17. Dujardin F. 1845. Histoire naturelle des helminthes ou vers intestinaux. Librairie Encyclopédique de Roret: Paris.

18. EELREP. 2005. Estimation of the reproduction capacity of European eel, Final Report, EU contract Q5RS-2001-01836. Available at http://www.fishbiology.net/eelrepsum.html

19. EU. 2007. Council Regulation (EC) No $1100 / 2007$ of 18 September 2007 establishing measures for the recovery of the stock of European eel. Official Journal of the European Union, L 248, 17-22.

20. Fazio G, Lecomte-Finiger R, Bartrina J, Moné H, Sasal P. 2005. Macroparasite community and asymmetry of the yellow eel Anguilla anguilla in Salses-Leucate lagoon, Southern France. Bulletin Français de la Pêche et de la Pisciculture, 378-379, 99113.

21. Feunteun E. 2002. Management and restoration of European eel population (Anguilla anguilla): an impossible bargain? Ecological Engineering, 18, 575-591.

22. Flegr J. 2008. Frozen Evolution: Or, that's not the way it is, Mr. Darwin - Farewell to selfish gene. Prague: Charles University, Faculty of Science.

23. Geeraerts C, Belpaire C. 2010. The effects of contaminants in European eel: a review. Ecotoxicology, 19, 239-266.

24. Goeze JAE. 1782. Versuch einer Naturgeschichte der Eingeweidewur-mer thierischer Korper. Blankenburg.

25. Grant SA, Brown JA. 1999. Variation in condition of coastal Newfoundland 0-group Atlantic cod (Gadus morhua): field and laboratory studies using simple condition indices. Marine Biology, 133, 611-620.

26. Gravato C, Guimaraes L, Santos J, Faria M, Alves A, Guilhermino L. 2010. Comparative study about the effects of pollution on glass and yellow eels (Anguilla anguilla) from the estuaries of Minho, Lima and Douro Rivers (NW Portugal). Ecotoxicology and Environmental Safety, 73, 524-533.
27. Haenen OLM, Van Banning P. 1990. Detection of larvae of Anguillicola crassus (an eel swimbladder nematode) in freshwater fish. Aquaculture, 87, 103-109.

28. Haenen OLM, Lehmann J, Engelsma MY, Stürenberg FJ, Roozenburg I. 2010. The health status of European silver eels, Anguilla anguilla, in the Dutch River Rhine watershed and Lake Ijsselmeer. Aquaculture, 309, 15-24.

29. Hurvich CM, Tsain CL. 1995. Model selection for extended quasi-likelihood models in small samples. Biometrics, 51, 1077-1084.

30. ICES. 2009. Annex 4: manual for the ageing of Atlantic eel. In: ICES Workshop on age reading of European and American eel (WKAREA), 20-24 April 2009, Bordeaux, France. ICES CM 2009, ACOM 48.

31. Jakob EM, Marshall SD, Uets GW. 1996. Estimating fitness: a comparison of body condition indices. Oikos, 77, 61-67.

32. Jakob E, Walter T, Hanel R. 2009. A checklist of the protozoan and metazoan parasites of European eel (Anguilla anguilla): checklist of Anguilla anguilla parasites. Journal of Applied Ichthyology, 1-49.

33. Kania PW, Taraschewski H, Han YS, Cone DK, Buchmann K. 2010. Divergence between Asian, European and Canadian populations of the monogenean Pseudodactylogyrus bini indicated by ribosomal DNA patterns. Journal of Helminthology, 84, 404-409.

34. Kennedy CR. 1994. The distribution and abundance of the nematode Anguillicola australiensis in eels Anguilla reinhardtii in Queensland, Australia. Folia Parasitologica, 41, 279-285.

35. Kennedy CR. 2007. The pathogenic helminth parasites of eels. Journal of Fish Diseases, 30, 319-334.

36. Kettle AJ, Vøllestad LA, Wibig J. 2011. Where once the eel and the elephant were together: decline of the European eel because of changing hydrology in southwest Europe and northwest Africa? Fish and Fisheries, 12, 380-411.

37. Køie M. 1988. Parasites in European eel Anguilla anguilla (L.) from Danish freshwater, brackish and marine localities. Ophelia, 29, 93-118.

38. Kristmundsson A, Helgason S. 2007. Parasite communities of eels Anguilla anguilla in freshwater and marine habitats in Iceland in comparison with other parasite communities of eels in Europe. Folia Parasitologica, 54, 141-153.

39. Kuwahara A, Niimi A, Itagaki H. 1974. Studies on the nematode parasitic on the air bladder of eel. I. Description of Anguillicola crassa n. Sp. (Philometridae, Anguillicolidae). Japanese Journal of Parasitology, 23, 275-279.

40. Lambert Y, Dutil JD. 1997. Can simple condition indices be used to monitor and quantify seasonal changes in the energy reserves of Atlantic cod (Gadus morhua)? Canadian Journal of Fisheries and Aquatic Sciences, 54, 104-112.

41. Le Cren ED. 1951. The length-weight relationship and seasonal cycle in gonad weight and condition in the perch (Perca fluviatilis). Journal of Animal Ecology, 20, 201-219.

42. Lefebvre F, Contournet P, Crivelli AJ. 2002. The health state of the eel swimbladder as a measure of parasite pressure by Anguillicola crassus. Parasitology, 124, 457-463.

43. Lefebvre F, Fazio G, Palstra AP, Székely C, Crivelli AJ. 2011. An evaluation of indices of gross pathology associated with the nematode Anguillicoloides crassus in eels. Journal of Fish Diseases, 34, 31-45.

44. Lefebvre F, Fazio G, Mounaix B, Crivelli AJ. 2013. Is the continental life of the European eel Anguilla anguilla affected 
by the parasitic invader Anguillicoloides crassus? Proceedings of the Royal Society B, 280, 20122916.

45. Linstow von OFB. 1878. Compendium of Helminthologie. Ein Verzeichniss der bekannt Helminthen, die frei oder in thierischen Korpern leven, geornet nach ihren Wohnthieren, unter der Organe, in denen sie gefunden sind, and mit Beifugung der Litteraturquellen. Hahn'ache Buchhandlung, Hannover.

46. MacHugh B, Poole R, Corcoran J, Anninou P, Boyle B, Joyce E, Foley MB, McGovern E. 2010. The occurrence of persistent chlorinated and brominated organic contaminants in the European eel (Anguilla anguilla) in Irish waters. Chemosphere, 79, 305-313.

47. Marcogliese DJ, Pietrock M. 2011. Combined effects of parasites and contaminants on animal health: parasites do matter. Trends in Parasitology, 27, 123-130.

48. Moravec F. 1992. Spreading of the nematode Anguillicola crassus (Dracunculoidea) among eel populations in Europe. Folia Parasitologica, 39, 247-248.

49. Moravec F. 1996. Aquatic invertebrates (snails) as new paratenic hosts of Anguillicola crassus (Nematoda: Dracunculoidea) and the role of paratenic hosts in the life cycle of this parasite. Diseases of Aquatic Organisms, 27, 237-239.

50. Müller OF. 1776. Zoologiae Danicae, Prodromus seu Animalium Daniae et Norvegiae Indigenarum characteres, nomina, et synonyma imprimis popularium. Copenhagen, Hallager.

51. Müller OF. 1780. Von Bandwürmern. Der Naturforscher, 14, 129-203.

52. Östlund-Nilsson S, Curtis L, Nilsson GE, Grutter AS. 2005. Parasitic isopod Anilocra apogonae, a drag for the cardinal fish Cheilodipterus quinquelineatus. Marine Ecology Progress Series, 287, 209-216.

53. Palstra AP, Heppener DFM, Van Ginneken VJT, Székely C, Van den Thillart GEEJM. 2007. Swimming performance of silver eels is severely impaired by the swimbladder parasite Anguillicola crassus. Journal of Experimental Marine Biology and Ecology, 352, 244-256.
54. Pangle KL, Sutton TM. 2005. Temporal changes in the relationship between condition indices and proximate composition of juvenile Coregonus artedi. Journal of Fish Biology, 66, 1060-1072.

55. Poole WR, Reynolds JD. 1996. Age and growth of yellow eel, Anguilla anguilla (L.), determined by two different methods. Ecology of Freshwater Fish, 5, 86-95.

56. Robinet T, Feunteun E. 2002. Sublethal effects of exposure to chemical compounds: a cause for the decline in Atlantic eels? Ecotoxicology, 11, 265-277.

57. Schrank van FP. 1787. Verzichniss der bisher hinlaneglich bekannten Eingeweidewürmer, nebts einer Abhandlungen über ihre Anverwandschaften, München.

58. Sjöberg NB, Petersson E, Wickström H, Hansson S. 2009. Effects of the swimbladder parasite Anguillicola crassus on the migration of European silver eels Anguilla anguilla in the Baltic Sea. Journal of Fish Biology, 74, 2158-2170.

59. Sutton SG, Bult TP, Haedrich RL. 2000. Relationships among fat weight, body weight, water weight, and condition factors in wild Atlantic salmon parr. Transactions of the American Fisheries Society, 130, 1-17.

60. Taraschewski H. 2000. Host-parasite interactions in acanthocephala: a morphological approach. Advances in Parasitology, $46,1-179$.

61. Thomas F, Guégan JF, Renaud F. 2007. Écologie et évolution des systèmes parasités. De Boeck \& Larcier, Bruxelles.

62. Woo PTK. 2006. Fish diseases and disorders. Volume 1. Protozoan and Metazoan infections. 2nd edn. CABI, Wallingford, UK.

63. Zimmerman JL, Welsh SA. 2012. Prevalence of Anguillicoloides crassus and growth variation in migrant yellow-phase American eels of the upper Potomac River drainage. Diseases of Aquatic Organisms, 101, 131-137.

Cite this article as: Gérard C, Trancart T, Amilhat E, Faliex E, Virag L, Feunteun E \& Acou A: Influence of introduced vs. native parasites on the body condition of migrant silver eels. Parasite, 2013, 20, 38.

\section{PARASTE}

An international open-access, peer-reviewed, online journal publishing high quality papers on all aspects of human and animal parasitology

Reviews, articles and short notes may be submitted. Fields include, but are not limited to: general, medical and veterinary parasitology; morphology, including ultrastructure; parasite systematics, including entomology, acarology, helminthology and protistology, and molecular analyses; molecular biology and biochemistry; immunology of parasitic diseases; host-parasite relationships; ecology and life history of parasites; epidemiology; therapeutics; new diagnostic tools.

All papers in Parasite are published in English. Manuscripts should have a broad interest and must not have been published or submitted elsewhere. No limit is imposed on the length of manuscripts.

Parasite (open-access) continues Parasite (print and online editions, 1994-2012) and Annales de Parasitologie Humaine et Comparée (1923-1993) and is the official journal of the Société Française de Parasitologie. 